\title{
ABRASIVE WEAR IN THREE-PHASE WASTE-BASED POLYMERIC PARTICLE COMPOSITES
}

\author{
Petr Valášek, Miroslav Müller
}

Original scientific paper

The experiment centres on two and three body abrasion in three-phase waste-based composite systems. The composite systems abrasion resistance is defined not only by the physical-mechanical relationships of the separate phases of the composite, but also by the mutual interaction of the phases and on the matrix-filler interface. To describe the composite system abrasion resistance, we used a "two-body" abrasive wear on an abrasive cloth and a "threebody" abrasive wear on a machine with a rubber disc using sand abrasion. The results show that we cannot find a clear correlation between the two- and three-body abrasions as far as the systems' volume decrease is concerned. At the same time, no clear relationship was confirmed between the hardness measured according to Brinell and the volume decreases with individual kinds of wear. The composite that proved the most resistant to abrasive wear was the one with $30 \%$ filler based 6:1 on metallic chips and the F80 fraction waste corundum in two-component epoxy (the volume decrease was $0,0395 \mathrm{~cm}^{3}$ by two body abrasion and $0,008 \mathrm{~cm}^{3}$ by three body abrasion)

Keywords: three-body abrasion; three-phase polymeric particle composite; two-body abrasion; waste

Abrazivno trošenje kod kompozita sastavljenih od čestica polimera s tri faze baziranih na otpadu

Izvorni znanstveni članak Eksperiment se zasniva na abraziji s dva i tri tijela u sustavima trofaznih kompozita od otpadnog materijala. Otpornost kompozitnih sustava na abraziju definira se ne samo fizikalno-mehaničkim odnosima pojedinih faza kompozita nego i uzajamnom interakcijom faza te međupovršinom matrica-punilo. Kako bismo opisali otpornost kompozitnog sustava na abraziju primijenili smo abrazivno trošenje "s dva tijela" na abrazivnom platnu i abrazivno trošenje "s tri tijela" na stroju s gumenim diskom uz abraziju pijeskom. Rezultati pokazuju da se ne može pronaći jasna korelacija između abrazija s dva i tri tijela sve dok se radi o smanjenju volumena sustava. U isto vrijeme, nije potvrđen jasan odnos između tvrdoće mjerene prema Brinellu i smanjenja volumena i pojedinačnih vrsta trošenja. Kompozit koji se pokazao najotpornijim na abrazivno trošenje bio je onaj s 30 \% punila koji se u odnosu 6:1 sastojao od metalnih strugotina i F80 frakcije otpada korunduma u dvo-komponentnoj epoksi smoli (smanjenje volumena bilo je $0,0395 \mathrm{~cm}^{3}$ kod abrazije s dva tijela i $0,008 \mathrm{~cm}^{3}$ kod abrazije s tri tijela).

Ključne riječi: abrazija s tri tijela; abrazija s dva tijela; čestica polimernog kompozita s tri faze; trošenje

\section{Introduction}

A polymeric particle composite is a material whose frame has the shape of particles not too different in individual parameters and whose matrix is a polymeric material, most often thermoset in the form of epoxy or polyester resin. This group of materials replaces other formerly conventionally used materials with increasing frequency and offers a wide space for material variation fulfilling the particular needs of application as well as its economic aspect. The experiment as described in this entry is proving the hypothesis that the inclusion of a secondary material into the polymeric matrix creates a brand new material showing properties similar to those of composites with a primary raw material. This entry deals with two waste-based fillers and their combinations: abrasion waste from the jet blasting process and the iron metallic chips (regular carbonated steel) from the milling process.

The composite materials use synergy of all their individual phases, which differ in their physical and chemical properties. The different physic-mechanical properties define their resulting tribologic properties. The presence of an anorganic filler with high abrasion resistance and correct interaction with the polymeric matrix change the resulting abrasion resistance considerably $[1,2]$. Lee et al. [3] counts among the critical factors with impact on abrasion resistance of the systems with hard frame also the properties of the interface and geometric and mechanical properties of the frame. The increased hardness of the matrix induced by the inclusion of frame impacts on the depth of invasion of the abrasive particles and decreases the volume of the ablated material $[2,4,5,6]$.

Sapathy et al. [7] found in their experiments with phenolic resins filled with corundum particles $40 \div$ $100 \mu \mathrm{m}$ in size that the addition of corundum increased abrasion resistance against two-body abrasive wear and the tensile strength of the material. At the same time, these authors discovered a clear correlation between abrasion resistance and hardness of the composite. Vocel et al. [8] filled epoxy resins with various kinds of anorganic particle fillers which had a significant influence on these composites' abrasion resistance as opposed to filler-free epoxy. Also Harsha et al. [9] state the improvement of three-body abrasion resistance with particle filler in their work. Considering the potential areas of application of the polymeric particle composites, increased hardness and abrasion resistance belong among the important properties to take into account. However, the experiments of the abovementioned authors were always conducted only with composites using primary material filler. Nowadays, the world-wide trend is mostly to use materials into their fullest and the application of secondary fillers into polymeric matrix is one of the possible ways to recycle some materials.

\section{Methodology}

Materials. The polymeric matrix of particle composites used for this experiment was epoxy resin. These materials are most often produced by the reaction 
of epichlorhydrine with bisphenol A. For the structure netting of these resins connected with curing, polyamines are used [10]. For carried out experiments, the twocomponent epoxy resin ECO-EPOXY 1200/324 with the curing agent P11 was chosen. The curing time of this resin is 24 hours at $23{ }^{\circ} \mathrm{C}$. The total curing occurs after 7 days. The moulds were made from the silicon rubber Lukopren N 1522. Before the mixture casting, the moulds were degreased in order to prevent any impact on the properties of the material. These moulds show the separation property towards the used resin. The mixture of epoxy resin and filler was mixed mechanically in an ultrasound basin to prevent the emergence of air bubbles and to guarantee the mixture's homogeneity.

As filler, a waste material produced by the jet blasting process and the iron metallic chips produced in the process of milling regular carbonated steel was used. In particular, it was artificial corundum of the F80 fraction, which was blasted on regular carbonated steel surface (pneumatic jet blasting chamber ITB 65, blasting time $120 \mathrm{~min}$, area of blasting $852 \mathrm{~cm}^{2}$, particle dimension before blasting $172 \pm 43 \mu \mathrm{m}$, particle dimension after blasting $147 \pm 52 \mu \mathrm{m}$ ). The metallic chips of the regular carbonated steel were milled by a circular cutter $\left(45^{\circ}-\right.$ $\varnothing 80 \mathrm{~mm}$, tooth count $20,63 \mathrm{rpm}$, advance $13 \mathrm{~mm} / \mathrm{min}-$ splinter surface area $520200 \pm 343900{\mu \mathrm{m}^{2}}^{2}$. These waste materials do not fall into the category of dangerous waste.

\subsection{Sample preparation}

The testing samples were prepared with the following volume percentage of the filler in the matrix $\left(v_{\mathrm{p}}\right): 20 \%$ and $30 \%$ according to the Eq. (1), which allowed easy system application and guaranteed good cohesion of the system and the adhesion to a prospective adherent. The formulation of the filler part by volume eliminates the influence of the different density between the matrix $(1,15$ $\mathrm{g} / \mathrm{cm}^{3}$ ) and the filler.

$v_{\mathrm{p}}=\frac{V_{\mathrm{p}}}{V_{\mathrm{c}}} \cdot 100$,

where:

$v_{\mathrm{p}}$ - filler volume percentages $(\%)$,

$V_{\mathrm{p}}-$ filler volume $\left(\mathrm{cm}^{3}\right)$,

$V_{\mathrm{c}}$ - total volume of composite $\left(\mathrm{cm}^{3}\right)$.

The theoretical density of the composite systems was calculated on the basis of the physical relationships, the actual density was stated on the basis of the ratio of weight and volume of the trial objects. An important firstclass quantity of the composite system - porosity $(P)$ was calculated according to the Eq. (2):

$$
P=\frac{\rho_{\text {The }}-\rho_{\text {Rea }}}{\rho_{\text {The }}} \cdot 100,
$$

where:

$P$ - porosity $(\%)$,

$\rho_{\text {The }}-$ theoretical composite density $\left(\mathrm{g} / \mathrm{cm}^{3}\right)$,

$\rho_{\text {Rea }}-$ real composite density $\left(\mathrm{g} / \mathrm{cm}^{3}\right)$.

\subsection{Image analysis}

To describe the representation of the individual phases in the area of abrasion on the composites, a stereomicroscope, a built-in camera and software were used. The obtained data were then statistically analysed.

\subsection{Experimental tests}

The test of hardness was based on the norm ČSN EN ISO 2039-1 [11]. Because of the size of the filler, a ball of hard metal with the diameter $D=10 \mathrm{~mm}$ was used. The trial burdening corresponded to $2,452 \mathrm{kN}$, the burdening time was $30 \mathrm{~s}$.

The two-body abrasive was tested on a rotating cylindrical drum device with the abrasive cloth of the grain size P120 according to the standard ČSN 621466 [12]. The testing machine with the abrasive cloth consists of the rotating drum on which the abrasive cloth is affixed by means of a bilateral adhesive tape. The testing specimen is secured in the pulling head and during the test it is shifted by means of a moving screw along the abrasive cloth from the left edge of the drum to the right one. The testing specimen is in contact with the abrasive cloth and it covers the distance of $60 \mathrm{~m}$. During one drum turn of $360^{\circ}$ it provoked the testing specimen left above the abrasive cloth surface. Consequent impact of the testing specimen simulates the concussion. The pressures force is $10 \mathrm{~N}$. The mean of the testing specimens was 15,5 $\pm 0,1 \mathrm{~mm}$ and their height was $20,0 \pm 0,1 \mathrm{~mm}$. The mass decreases were measured on analytic scales weighing on $0,1 \mathrm{mg}$. The volume decreases were calculated on the basis of the found out volume and the density of the composite systems.

For the experimental definition of three-body abrasion we used a machine with a rubber disc which simulates the process of abrasive wear by free particles. The particles used for the experiment were the particles of fire sand with grain size between $0,200 \div 0,315 \mathrm{~mm}$ (the sand for this fraction was suctioned there through mesh screens). The trial specimen with the size $39,0 \pm 0,1 \mathrm{~mm}$, $24,5 \pm 0,1 \mathrm{~mm}$ and $8,0 \pm 0,1 \mathrm{~mm}$ was pressed to the rubber disc by a pressing force of $36,4 \mathrm{~N}$, the diameter of the disc was $130 \mathrm{~mm}$ and the frictional distance $250 \mathrm{~m}$. The approach described is modifying the regulation ASTM G65 see Fig. 1 [13].

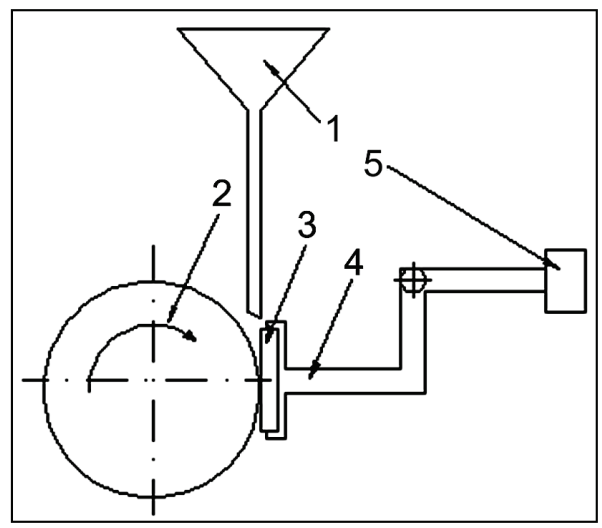

Figure 1 The machine with the rubber disc 1 - funnel, 2 - rubber disc, 3 - test specimen, 4 - handle, 5 - weight 


\section{Results}

The results presented here compare the waste-based composite systems with epoxy resin without filler and two composite systems on a similar basis commonly available in retail establishments (Lepox Metal, Eprosin T30). One of the properties defining the qualities of the composite systems is their porosity, which influences the wholesomeness of the material and the epoxy-filler interface. Therefore, it has direct influence on the mechanical properties. According to Berthelot [14], the composite systems with porosity under $5 \%$ should be considered as very high quality. During the preparation of the systems, no vacuum was used, the reason for this being continuity of our best practices - the demand of minimal expenses when equipping a workplace for the application. This fact is one of the factors leading to the increased porosity. Table 1 shows the theoretical density $\left(\rho_{\text {The }}\right)$ and porosity $(P)$ of the individual composite systems. At the same time, Tab. 1 shows the representation of iron chips as one of the three phases of the composites on the surfaces, where there is two-body (M1) and three-body (M2) abrasion. This fact is expressed by the arithmetic average of the percentage of the phase on the used surface of the specimen. The density of the epoxy corresponded to $1,15\left(\mathrm{~g} / \mathrm{cm}^{3}\right)$. The orientation, distribution and shape of the composite particles on this surface define its abrasion resistance.

Table 1 Basic mechanical properties and the proportion of phases $(*$ the manufacturer does not state density after curing, the figures stated here

\begin{tabular}{|l|c|c|c|c|c|}
\hline \multicolumn{1}{|c|}{ Material } & $v_{\mathrm{p}} / \%$ & $\begin{array}{c}\rho_{\text {The }} / \\
\mathrm{g} / \mathrm{cm}^{3}\end{array}$ & $P / \%$ & $\mathrm{M} 1 / \%$ & $\mathrm{M} 2 / \%$ \\
\hline F80 & 20 & 1,7 & 7,0 & - & - \\
\hline Chips & 20 & 2,5 & 4,0 & 25,7 & 23,2 \\
\hline Chips: F80 1:1 & 20 & 2,1 & 7,2 & 21,7 & 23,9 \\
\hline Chips: F80 1:2 & 20 & 2,0 & 4,5 & 19,4 & 19,2 \\
\hline Chips: F80 2:1 & 20 & 2,3 & 3,6 & 26,3 & 22,6 \\
\hline Chips: F80 6:1 & 20 & 2,3 & 3,8 & 26,0 & 23,7 \\
\hline Chips: F80 1:6 & 20 & 1,8 & 9,4 & 20,3 & 14,1 \\
\hline F80 & 30 & 1,7 & 7,0 & - & - \\
\hline Chips & 30 & 3,2 & 6,6 & 27,0 & 23,7 \\
\hline Chips: F80 1:1 & 30 & 2,4 & 7,4 & 23,5 & 26,9 \\
\hline Chips: F80 1:2 & 30 & 2,3 & 8,6 & 22,2 & 20,0 \\
\hline Chips: F80 2:1 & 30 & 2,6 & 4,3 & 24,2 & 24,2 \\
\hline Chips: F80 6:1 & 30 & 3,0 & 4,9 & 25,8 & 24,9 \\
\hline Chips: F80 1:6 & 30 & 2,2 & 6,2 & 20,7 & 19,4 \\
\hline Lepox Metal* & - & 2,0 & - & - & - \\
\hline Eprosin T30* & - & 1,7 & - & - & - \\
\hline
\end{tabular}

The following Fig. 2 illustrates the representation of the phase of metallic chips. The filler in the form of metallic chips is marked white, the matrix and the corundum grain are black. Since the method used on the specimen subjected to the two-body abrasion did not enable us to evaluate the corundum particles representation, only the percentage of metallic chips in the material could be recorded (see Tab. 1 M1 and M2).

From the ratio of phases as found by the image analysis it is obvious that it is not possible to prove a distinct influence of the concentration of the phase on the experimentally established representation of the phase on the worn surface of the composite. This fact is given by the variable shape and size of the individual phases and by the sedimentation process which occurs during the hardening of the epoxy resin ( 24 hours), when the individual filler particles react to each other. The setting of the particles also influences the materials abrasion resistance itself. The dependence of the hardness of the composite on the resistance to two-body abrasion is shown in the following graph (Fig. 3). Mean root square errors of the mentioned arithmetic average figures have not surpassed $15 \%$.

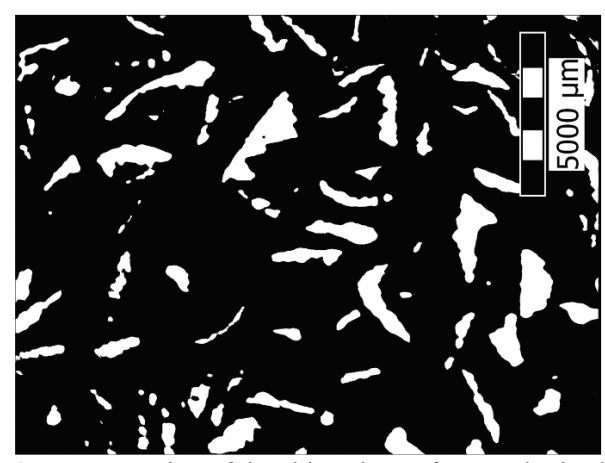

Figure 2 Representation of the chips phase after two-body abrasion; chips: F80 1:1, $20 \%$ of chips

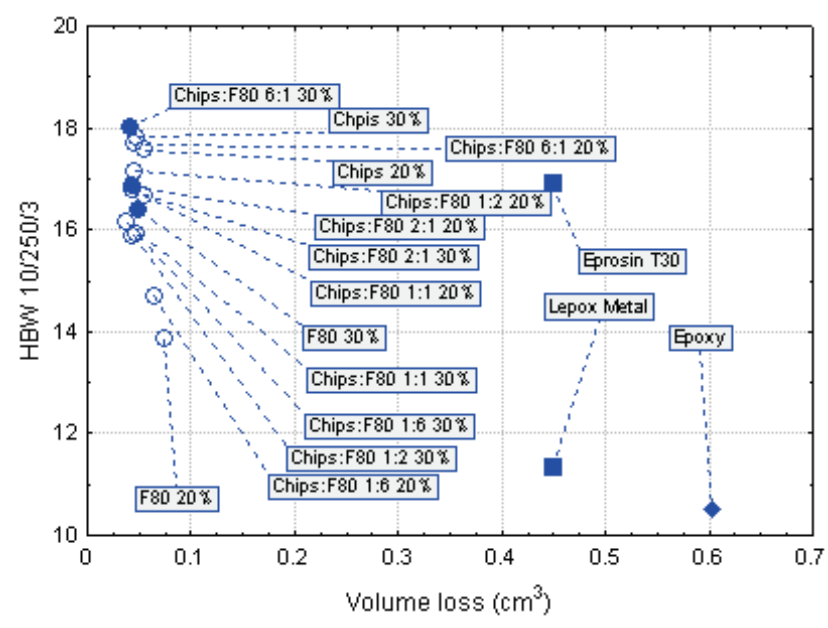

Figure 3 Impact of the hardness of the materials on two-body abrasion resistance

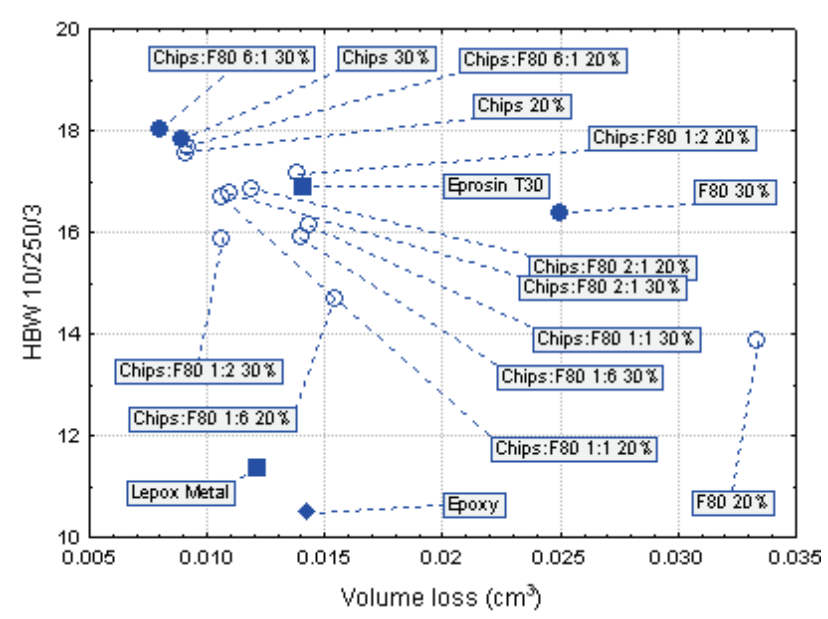

Figure 4 Impact of the hardness of the materials on three-body abrasion resistance

From the data measured it is obvious that all the waste-based composite systems have registered increased resistance towards two-body abrasion in comparison to 
the filler-less epoxy. The most resistant system was the one with $30 \%$ filler in the matrix with the combination $1: 1$ (volume decrease $0,0385 \pm 0,002 \mathrm{~cm}^{3}$ ) and $6: 1$ (volume decrease $\left.0,0395 \pm 0,003 \mathrm{~cm}^{3}\right)$. The resistance of these materials is 15,6 times higher than the resistance of a filler-less epoxy resin $\left(0,6033 \pm 0,014 \mathrm{~cm}^{3}\right)$. The highest value in hardness, 8,2 HBW 10/250/30, was recorded by the system with $30 \%$ of filler in the matrix $6: 1$. However, we cannot speak of a clear correlation between hardness and two-body abrasion resistance. These results relate to abrasive cloth with the grain size of P120. The decrease in volume caused by the three-body abrasion depending on the hardness measured is shown in Fig. 4.

With three-body abrasion, the improved resistance of the composites in comparison to the epoxy resin with no filler is not clear (decrease in volume 0,014 \pm $\left.0,001 \mathrm{~cm}^{3}\right)$. Composites consisting only of the F80 phase have a lower resistance to three-body abrasion than epoxy. It is safe to say that the metallic chips improve its resistance tremendously even with a tiny representation of F80. The most prominent resistance to three-body abrasion was recorded with a composite with $30 \%$ of filler in the matrix 6:1 - volume decrease 0,008 \pm $0,001 \mathrm{~cm}^{3}$. The mean root square errors in the stated average figures have not reached past $30 \%$. The high mean root square errors were probably caused by chipping of the corundum as well as the porosity of the material. The concrete numbers for the smallest volume decreases in comparison to both types of wear are recorded in Fig. 5.

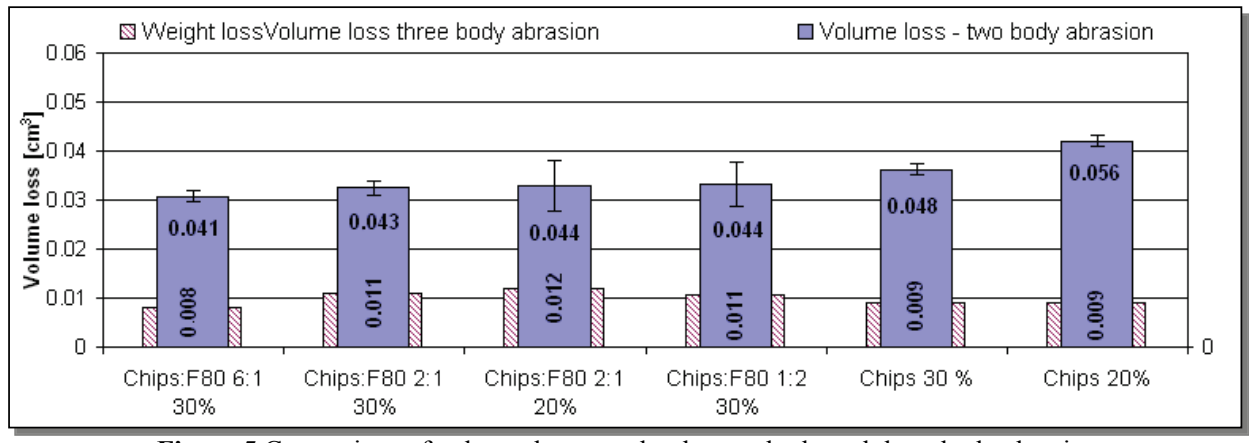

Figure 5 Comparison of volume decreases by the two-body and three-body abrasion

If we evaluate the composite systems on the basis of both kinds of abrasion, the lowest volume decrease was recorded for the system with $30 \% 6: 1$. If the system is resistant towards two-body abrasion, this does not mean that it will show a similar resistance during three-body abrasion. This fact is given by the varied process of wear clear from Figs. 6 and 7.

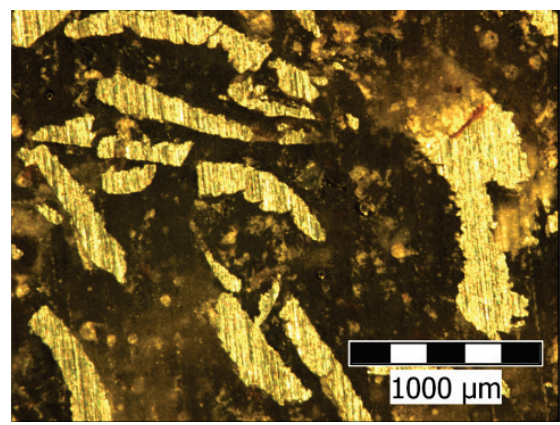

Figure 6 The structure of a worn surface of the composite $30 \% 1: 1$, two-body abrasion

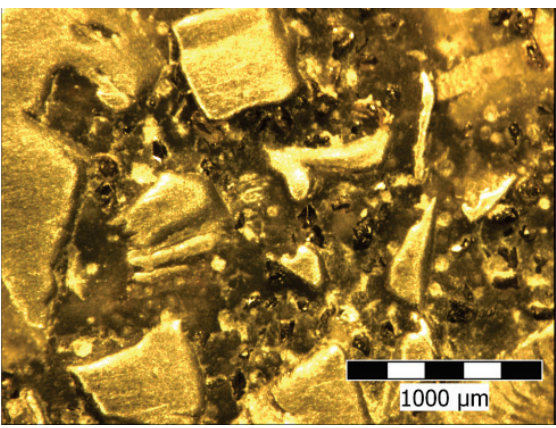

Figure 7 The structure of a worn surface of the composite $30 \% 1: 1$, three-body abrasion

During two-body abrasion the same type of wear occurred in all the composite systems at the same time smooth surface. During three-point abrasion parts of filler became uncovered and in case of F80 were chipped off, whereas the iron chips did not chip off. The resulting surface was coarse and unevenly worn. This fact led to the statement that only the F80 phase in the resin was decreasing its resistance.

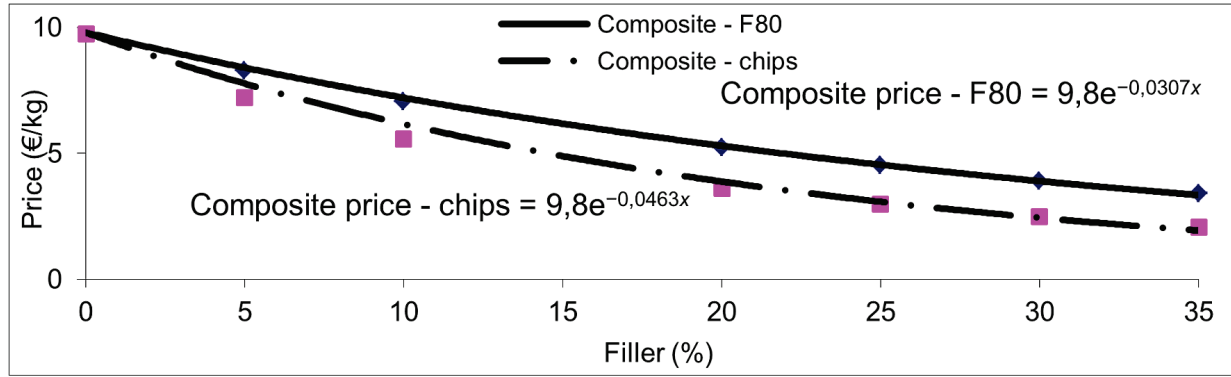

Figure 8 Description of the price of the waste-based composites 
Fig. 8 shows clearly the price of waste-based composite systems (stemming from the price of the epoxy resin $9,8 € / \mathrm{kg}$ ). The functional equations describe the flow of the price up till the concentration reaches $35 \%$ of filler in the matrix, since this percentage can be considered the borderline limit as far as the composite's applicability to the adherent surface is concerned. The exponential trend is caused by the calculations including filler and matrix density (volume percentage).

The price of Lepox Metal in 2012 has been on the border of $58,6 € / \mathrm{kg}$ and the price of Eprosin $\mathrm{T} 30$ corresponded to $95 € / \mathrm{kg}$. It is necessary to add that these prices concern the $150 \mathrm{~g}$ and $40 \mathrm{~g}$ packaging usually sold in retail stores in the Czech Republic. The prices can therefore be taken only as guidelines, but even so, the considerable economy in applying these epoxy resins with waste-based filler is clear.

\section{Discussion}

The aim of this experiment was to describe the resistance of multi-phased composite systems with waste-based filler towards two-body and three-body abrasion and thus to confirm the hypothesis that a secondary material can be used as a filler. In scientific theses, the authors describe the theme of particle composites in great detail, but the possibility of the application of waste-based particle filler produced by the jet blasting waste and metallic chips into epoxy resins was not yet described in any of the accessible sources. By adding waste-based filler into epoxy resin, two qualitatively brand new materials were created, which confirmed the assumption of Kim et al. [15], who credit this fact to the mutual interaction between the appropriate components of the composite system. The application of waste-based fillers into epoxy resin had a significant impact on its resistance to abrasive wear. This fact confirmed the conclusions of Stewart et al. [16], who state the ability of epoxy resins to be modified by various kinds of fillers. The behaviour of the composites with only the phase F80 $(147 \mu \mathrm{m})$ confirms the conclusions of Xian Jia et al. [17], who set an interval by primary corundum which influences high resistance towards abrasive wear to 40,5 till $161 \mu \mathrm{m}$. With anorganic waste filler it is possible to agree with the statement arising from the work of Sataphy et al. [7], who found out that this inclusion will increase resistance towards two-body abrasion. Resistance of two and three-body abrasion varies from one waste-based composite system to another and so it is not possible to agree with the conclusion of Kumar et al. [18] and Suresha [19], who state that if the composite system is resistant during two-body abrasion, this characteristic would be prominent also by three-body abrasion.

\section{Conclusion}

The conclusions arising from the experiment conducted with multiple-phase waste-based composites can be summarized in the following points:

- The hypothesis about the replacement of a primary material with a secondary one in the form of fillers of the composite system resistant towards abrasive wear was confirmed.

- This fact leads to the possibility of a cheap form of material recycling, which is environmentally friendly and as such should be preferred.

- With two-body abrasion, the specimens with wastebased filler were in all cases more resistant towards abrasive wear than epoxy without filler and the evaluated binder with organic filler (more than $16 \times$ ).

- With three-body abrasion, the systems with a high percentage of chips were more resistant towards abrasion than the epoxy itself (approximately 1,7×).

- With the two-body as well as three-body abrasion, no clear correlation between hardness and resistance of the systems was found.

- All in all, it is impossible to state a clear correlation between the two- and three-body abrasive wear where their volume decreases are concerned.

\section{Acknowledgement}

This paper has been done when solving the IGA TF grant (no. 31140/1312/3104).

\section{References}

[1] Kruschov, M. M. Principles of abrasive wear. // Wear. 28, (1974), pp. 69-88. DOI: 10.1016/0043-1648(74)90102-1

[2] Suchánek, J.; Kuklík, V.; Zdravecká, E. Abrazivní opotřebení materiálů (Abrasive wear of materials). Prague, 2007.

[3] Lee, G. Y.; Dharan, C. K. H.; Ritchie, R. O. A physicallybased abrasive wear model for composite materials. // Wear. 252, (2002), pp. 322-331. DOI: 10.1016/S00431648(01)00896-1

[4] Müller, M.; Valášek, P. et al. Aplikace návarů a kompozitů v oblasti technologie pěstování a sklizně cukrové řepy (Overlays and composites application in technology of sugar beet cultivation and harvest). // Listy cukrovarnické a řepařské. 9, (2011), pp. 304-307.

[5] Müller, M.; Valášek, P. Interaction of steel surface treatment by means of abrasive cloth and adhesive bond strength. // Manufacturing Technology. 14, (2010), pp. 4957.

[6] Dogan, C. P.; Hawk, J. K. Role of zirconia toughening in the abrasive wear of intermetalic and ceramic composites. // Wear. 212, 1(1997), pp. 110-118. DOI: 10.1016/S00431648(97)00114-2

[7] Satapathy, B. K.; Bijwe, J. Analysis of simultaneous influence of operating variables on abrasive wear of phenolic composites. // Wear. 253, (2002), pp. 787-794. DOI: 10.1016/S0043-1648(02)00158-8

[8] Vocel, M.; Dufek, V. Tření a opotřebení strojních součástí (The friction of machine parts). Prague: SNTL, 1976.

[9] Harsha, A. P.; Tewari, U. S.; Venkatraman, B. Three-body abrasive wear behaviour of polyaryletherketone composites. // Wear. 254, (2003), pp. 680-692. DOI: 10.1016/S0043-1648(03)00142-X

[10] Vojtěch D. Materiály ajejich mezní stavy (Materials and their marginal status). Prague: VŠCHT, 2010.

[11] ČSN EN ISO 2039-1. Plastics - Determination of hardness Part 1: Ball indentation method, 2000.

[12] ISO 62 1466. Rubber; Determination of abrasion resistance using a rotating cylindrical drum device, 1985.

[13] ASTM G65. Standard Test Method for Measuring Abrasion Using the Dry Sand/Rubber Wheel Apparatus ASTM G65, 2010. 
[14] Berthelot, J. M. Composite Materials - Mechanical Behavior and Structural Analysis. Berlin: Mechanical engineering series, 1998.

[15] Byung Chul Kim; Sang Wook Park; Dai Gil Lee. Fracture toughness of the nano-particle reinforced epoxy composite. // Composite Structures, Elsevier. 86, 1-3(2008), pp. 69-77. DOI: 10.1016/j.compstruct.2008.03.005

[16] Stewart, I.; Chambers, A.; Gordon, T. The cohesive mechanical properties of a toughened epoxy adhesive as a function of cure level. // International Journal of Adhesion and Adhesives. 27, 4(2006), pp. 277-287. DOl: 10.1016/j.ijadhadh.2006.05.003

[17] Xia Jia; Xiaomei Ling. Influence of $\mathrm{Al}_{2} \mathrm{O}_{3}$ reinforcement on the abrasive wear characteristic of $\mathrm{Al}_{2} \mathrm{O}_{3} / \mathrm{PA} 1010$ composite coatings. // Wear. 258, 9(2005), pp. 1342-1347. DOI: 10.1016/j.wear.2004.10.003

[18] Ravi Kumar, B. N.; Suresha, B.; Venkataramareddy, M. Effect of particulate fillers on mechanical and abrasive wear behaviour of polyamide 66/polypropylene nanocomposites. // Material and Design. 30, 9(2009), pp. 3852-3858. DOI: 10.1016/j.matdes.2009.01.034

[19] Suresha, B.; Ravi Kumar, B. N. Two-Body Abrasive Wear Behavior of Particulate Filled Polyamide66/Polypropylene Nanocomposites. // Journal of Applied Polymer Science. 119, 4(2009), pp. 2292-2301. DOI: 10.1002/app.32909

\section{Authors' addresses}

Petr Valášsk, Ing., Ph.D.

Department of Material Science and Manufacturing Technology,

Faculty of Engineering, Czech University of Life Science,

Kamýcká 129, 16521 Prague, Czech Republic

E-mail: valasekp@tf.czu.cz

Miroslav Müller, Assoc. prof., Ing., Ph.D.

Department of Material Science and Manufacturing Technology,

Faculty of Engineering, Czech University of Life Science,

Kamýcká 129, 16521 Prague, Czech Republic

E-mail: muller@tf.czu.cz 